\title{
Range extension of the Peale's Free-tailed Bat Nyctinomops aurispinosus (Molossidae) in Brazil
}

\author{
Gledson Vigiano Bianconi ${ }^{1,4}$, Renato Gregorin $^{2} \&$ Daniel Carvalho Carneiro ${ }^{3}$ \\ ${ }^{1}$ Programa de Pós-graduação em Ciências Biológicas - Zoologia, \\ Universidade Estadual Paulista - UNESP, \\ CP 199, CEP 13506-900 Rio Claro, SP, Brazil \\ ${ }^{2}$ Departamento de Biologia, Universidade Federal de Lavras - UFLA, \\ CP 3037, CEP 37200-000 Lavras, MG, Brazil \\ ${ }^{3}$ Departamento de Zoologia e Botânica, Universidade Estadual Paulista - UNESP, \\ São José do Rio Preto, SP, Brazil \\ ${ }^{4}$ Corresponding author: Gledson Vigiano Bianconi, e-mail: bianconi@terra.com.br
}

BIANCONI, G.V., GREGORIN, R. \& CARNEIRO, D.C. Range extension of the Peale's Free-tailed Bat Nyctinomops aurispinosus (Molossidae) in Brazil. Biota Neotrop., 9(2) http://www.biotaneotropica.org.br/ v9n2/en/abstract?short-communication+bn02409022009.

Abstract: There is a lack of knowledge of the biology and distribution of Nyctinomops aurispinosus. Herein, we report the southernmost record of this species, from the city of Curitiba (25 $25^{\prime} \mathrm{S}$ and $\left.49^{\circ} 15^{\prime} \mathrm{W}, 920 \mathrm{~m}\right)$, state of Paraná, Brazil, and summarize its distribution in South America.

Keywords: Chiroptera, distribution, Molossidae, new record, South America.

BIANCONI, G.V., GREGORIN, R. \& CARNEIRO, D.C. Ampliação da distribuição de Nyctinomops aurispinosus (Molossidae) no Brasil. Biota Neotrop. Apr/Jun 2009 9(2) http://www.biotaneotropica.org.br/ v9n2/pt/abstract?short-communication+bn02409022009.

Resumo: Há uma grande lacuna no conhecimento da biologia e corologia de Nyctinomops aurispinosus. Nesta comunicação, nós apresentamos o registro mais austral deste molossídeo, realizado na cidade de Curitiba $\left(25^{\circ} 25^{\prime} \mathrm{S}\right.$ e $49^{\circ} 15^{\prime}$ W, 920 m), estado do Paraná, Brasil, e sumarizamos a distribuição geográfica conhecida para a espécie na América do Sul.

Palavras-chave: Chiroptera, distribuição, Molossidae, novo registro, América do Sul. 


\section{Introduction}

Presently, four species are recognized within the New World molossid bat genus Nyctinomops Miller, 1902: N. aurispinosus (Peale, 1848), N. laticaudatus (E. Geoffroy, 1805), N. macrotis (Gray, 1840), and $N$. femorosaccus (Merriam, 1889). Only the latter does not occur in Brazil (Koopman 1982, Simmons 2005). Nyctinomops was described by Miller (1902), who included eight species in the genus, and the type-species is N. femorosaccus. Later, Nyctinomops was considered a synonym of Tadarida by Shamel (1931), who included four species in the macrotis-group that was subsequently designated as a subgenus of Tadarida (e.g. Koopman 1982). Freeman (1981) recognized Nyctinomops as a valid genus, with which we concur. Species of Nyctinomops are distinguishable from other molossid species in having 1) deeply wrinkled upper lips, 2) ears touching each other over forehead, 3) upper incisors parallel and separated from each other by a gap due to a narrow and long maxillary emargination, 4) long and narrow rostrum, 5) very deep basisphenoid pits, 6) plagiocrest and protoloph paralleling each other in the first two upper molars, and 7) two pairs of lower incisors (Freeman 1981, Legendre 1984, Gregorin 2000, Gregorin \& Taddei 2002).

Nyctinomops aurispinosus is distributed from northwestern Mexico to southern South America with records in Venezuela, Colombia, Peru, Bolivia, and Brazil (Carter \& Davis 1961, Taddei \& Garutti 1981, Ochoa 1984, Ibáñez \& Ochoa 1989, Eger 2007; Figure 1). The type-locality of the species is $161 \mathrm{~km}$ off Cape São Roque, State of Rio Grande do Norte, Brazil, or more precisely "on board the U.S.S. Peacock off the coast of Brazil [...] about 100 miles from land, south of Cape St. Roque" (Shamel 1931: p. 12). Nyctinomops aurispinosus is a biometrically intermediary species within the genus (Taddei \& Garutti 1981, Ochoa 1984, Ibáñez \& Ochoa 1989, Jones \& Arroyo-Cabrales 1990, Gregorin \& Taddei 2002). Dorsal pelage is usually dark brown but also varies from reddish to grayish-brown (Jones \& Arroyo-Cabrales 1990). Shamel (1931) mentioned the note made by Gerrit Miller, "belly wood brown, back between wood brown and russet". However, specimens of $N$. aurispinosus in collections are very scarce, affecting our comprehension of the variation of characters throughout its distribution. The purpose of this paper is to report a range extension of $N$. aurispinosus in Brazil, and present a summary of the known distribution of this species in South America.

\section{Material and Methods}

On 11 April 2005 a male specimen of Nyctinomops was captured alive on the ninth floor of an apartment in Curitiba municipality, State of Paraná, Brazil (25 $25^{\prime} \mathrm{S}$ e $49^{\circ} 15^{\prime} \mathrm{W}, 920 \mathrm{~m}$ a.s.l.). The specimen was sent to the State Central Laboratory (Secretaria de Estado da Saúde do Paraná) and it was diagnosed as rabies-negative. It is currently preserved in alcohol at the Departamento de Biologia of the Universidade Federal de Lavras, Brazil (field-number RA 24116). The specimen had its skull removed, which was much damaged with the basicranium broken. Linear measurements of external and craniodental dimensions are reported in millimeters $(\mathrm{mm})$.

\section{Results and Discussion}

Pelage coloration agrees with what is known for the species, and although measurements are slightly larger than the variation recorded for other Brazilian and South American specimens (Table 1), we considered the specimen as being identifiable as $N$. aurispinosus. Among the species of Nyctinomops that occur in Brazil, there is a gap in our knowledge of the biology and distribution of $N$. aurispinosus with scarce records for the states of Rio Grande do Norte (type-

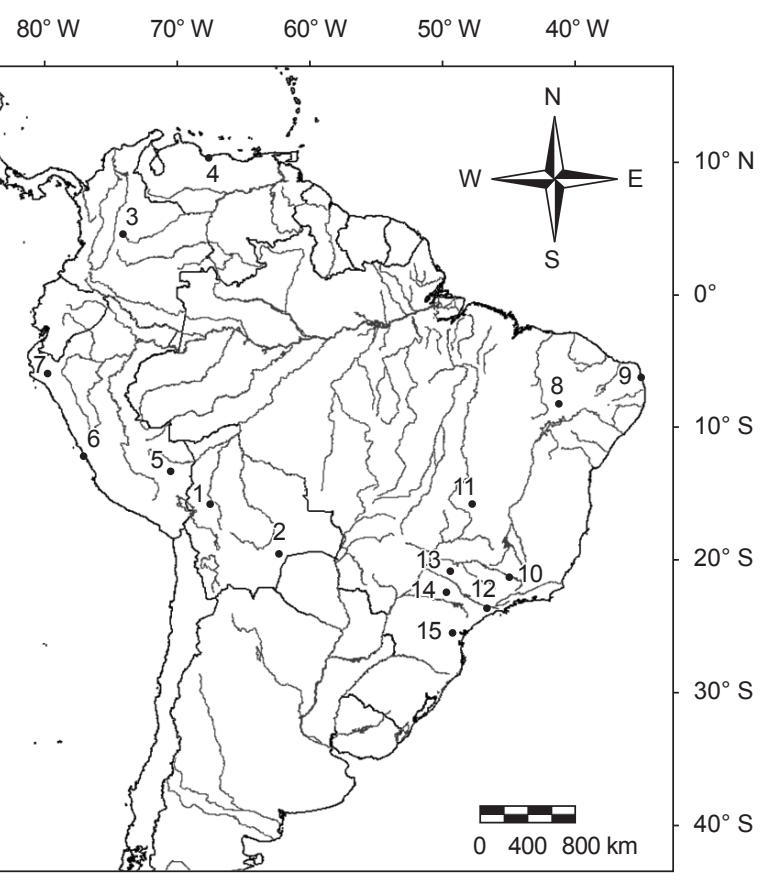

Figure 1. Known distribution of Nyctinomops aurispinosus in South America (1-14), including the new record presented herein (15). 1. Bolivia: La Paz, La Reserva, 15 44' S-67 31' W (Anderson 1997); 2. Bolivia: Santa Cruz, Hacienda Cerro Colorado, $19^{\circ} 27^{\prime}$ S-62 $2^{\circ} 21^{\prime}$ W (Ibáñez \& Ochoa 1989); 3. Colombia: Cundinamarca, Bogotá (type locality of Tadarida similis - synonym) (Sanborn 1941), 04 36' N-74 ${ }^{\circ}$ 05' W (Gardner 2007); 4. Venezuela: Aragua, Rancho Grande, $10^{\circ} 21^{\prime}$ N-67²0' W (Ochoa 1984);

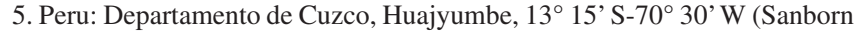
1951, Koopman 1978, Eger 2007); 6. Peru: Departamento de Lima, Lima, Cerro Agustino, 12 $2^{\circ} 06^{\prime}$ S-77 00' W (Ortiz de la Puente 1951); 7. Peru: Lambayeque, $12 \mathrm{~km}$ N of Olmos, $05^{\circ} 55^{\prime}$ S-79 47' W (Eger 2007); 8. Brazil: State of Piauí, Paulistana, $08^{\circ} 09^{\prime}$ S $-41^{\circ} 09^{\prime} \mathrm{W}$, locality cited Morro do Chapéu (Vizotto et al. 1980); 9. Brazil: State of Rio Grande do Norte, 100 miles from land, south of Cape St. Roque (type-locality), coordinates unknown (Shammel 1931); 10. Brazil: State of Minas Gerais, Lavras, $21^{\circ} 14^{\prime} \mathrm{S}-45^{\circ} 00^{\prime} \mathrm{W}$ (Tavares et al. in press); 11. Brazil: Distrito Federal, $15^{\circ} 45^{\prime} \mathrm{S}-47^{\circ} 45^{\prime} \mathrm{W}$ (Bredt 2003); 12. Brazil: State of São Paulo, São Paulo, $23^{\circ} 32^{\prime}$ S-46 $37^{\circ}$ 'W (Silva et al. 1996); 13. Brazil: State of São Paulo, São José do Rio Preto, $20^{\circ} 49^{\prime}$ S-49 23' W (Taddei \& Garutti 1981); 14. Brazil: State of São Paulo, Estação Ecológica dos Caetetus, $22^{\circ} 25^{\prime}$ S-49 ${ }^{\circ}$ 42' W (Pedro et al. 2001); 15. Brazil: State of Paraná, Curitiba, $25^{\circ} 25^{\prime} \mathrm{S}-49^{\circ} 15^{\prime} \mathrm{W}$ (new record).

Figura 1. Distribuição conhecida de Nyctinomops aurispinosus na América do Sul (1-14), incluindo o novo registro (15). 1. Bolívia: La Paz, La Reserva, $15^{\circ} 44^{\prime}$ S $-67^{\circ} 31^{\prime}$ W (Anderson 1997); 2. Bolívia: Santa Cruz, Hacienda Cerro Colorado, $19^{\circ} 27^{\prime}$ S-62 21' W (Ibáñez \& Ochoa 1989); 3. Colômbia: Cundinamarca, Bogotá (localidade tipo de Tadarida similis - sinônimo) (Sanborn 1941), 04 36' N-74 05' W (Gardner 2007); 4. Venezuela: Aragua, Rancho Grande, $10^{\circ} 21^{\prime}$ N-67 ${ }^{\circ}$ 40'W (Ochoa 1984); 5. Peru: Departamento de Cuzco, Huajyumbe, $13^{\circ} 15^{\prime}$ S-70³0' W (Sanborn 1951, Koopman 1978, Eger 2007); 6. Peru: Departamento de Lima, Lima, Cerro Agustino, $12^{\circ} 06^{\prime} \mathrm{S}-77^{\circ}$ 00' W (Ortiz de la Puente 1951); 7. Peru: Lambayeque, 12 km N de Olmos, 05 ${ }^{\circ} 55^{\prime}$ S-79 47' W (Eger 2007); 8. Brasil: Estado do Piauí, Paulistana, $08^{\circ} 09^{\prime}$ S-41 ${ }^{\circ} 09^{\prime} \mathrm{W}$, localidade citada Morro do Chapéu (Vizotto et al. 1980); 9. Brasil: Estado do Rio Grande do Norte, 100 milhas do continente, sul do Cabo de São Roque (localidade-tipo), coordenadas desconhecidas (Shammel 1931); 10. Brasil: Estado de Minas Gerais, Lavras, $21^{\circ} 14^{\prime} \mathrm{S}-45^{\circ} 00^{\prime} \mathrm{W}$ (Tavares et al. in press); 11. Brasil: Distrito Federal, $15^{\circ} 45^{\prime}$ S $-47^{\circ} 45^{\prime} \mathrm{W}$ (Bredt 2003); 12. Brasil: Estado de São Paulo, São Paulo, $23^{\circ} 32^{\prime}$ S-46 $37^{\prime}$ W (Silva et al. 1996); 13. Brasil: Estado de São Paulo, São José do Rio Preto, 20 49' S-49²3' W (Taddei \& Garutti 1981); 14. Brasil: Estado de São Paulo, Estação Ecológica dos Caetetus, $22^{\circ} 25^{\prime}$ S-49 $42^{\prime}$ W (Pedro et al. 2001); 15. Brasil: Estado do Paraná, Curitiba, $25^{\circ} 25^{\prime}$ S-49 ${ }^{\circ} 15^{\prime} \mathrm{W}$ (novo registro). 
Range extension of Nyctinomops aurispinosus

Table 1. Measurements (mm) of Nyctinomops aurispinosus from Brazil: State of Paraná, Curitiba (our specimen); State of São Paulo, São José do Rio Preto (Taddei \& Garutti 1981); State of Piauí, Paulistana (Vizotto et al. 1980); and Colômbia (Carter \& Davis 1961), Peru (Carter \& Davis 1961) and Bolivia (Ibáñez \& Ochoa 1989).

Tabela 1. Medidas (mm) de Nyctinomops aurispinosus do Brasil: Estado do Paraná, Curitiba (nosso espécime); Estado de São Paulo, São José do Rio Preto (Taddei \& Garutti 1981); Estado do Piauí, Paulistana (Vizotto et al. 1980); e Colômbia (Carter \& Davis 1961), Peru (Carter \& Davis 1961) e Bolívia (Ibáñez \& Ochoa 1989).

\begin{tabular}{|c|c|c|c|c|c|c|c|}
\hline Measurements & $\begin{array}{c}\text { Paraná } \\
\text { Brazil }\end{array}$ & $\begin{array}{c}\text { São Paulo } \\
\text { Brazil }\end{array}$ & $\begin{array}{c}\text { Piauí } \\
\text { Brazil }\end{array}$ & Colombia & Peru & Bolivia & Bolivia \\
\hline & 1 male & 1 male & 4 females & 1 male & female & 4 females & 4 males \\
\hline Length of head and body & 71.2 & 73.0 & $70.6(69.7-71.6)$ & - & - & - & - \\
\hline Length of tail & 45.3 & - & $44.1(40.7-46.6)$ & - & - & - & - \\
\hline Length of forearm & 53.4 & 51.5 & $51.2(50.4-51.9)$ & 49.5 & 51.5 & $49.7(48.7-50.3)$ & $51.0(50.3-52.8)$ \\
\hline Length of metacarpal III & 51.6 & 51.0 & $47.3(46.0-48.1)$ & - & 48.4 & - & - \\
\hline Length of metacarpal IV & 50.7 & 50.6 & $45.2(43.6-46.2)$ & - & 46.8 & - & - \\
\hline Length of metacarpal V & 28.9 & 31.0 & $25.3(25.1-25.6)$ & - & 26.9 & - & - \\
\hline Length of ear & 22.5 & - & $21.1(20.2-21.5)$ & - & 29.0 & - & - \\
\hline Breadth across upper molars & 8.3 & 8.2 & $8.1(7.9-8.3)$ & 8.5 & 8.4 & $8.4(8.3-8.6)$ & $8.7(8.6-8.7)$ \\
\hline Breadth across upper canines & 4.7 & 4.7 & $4.2(4.2-4.4)$ & 4.7 & 4.9 & - & - \\
\hline Length of upper toothrow & 8.1 & 8.1 & $7.4(7.3-7.6)$ & 7.8 & 7.8 & $7.9(7.8-8.0)$ & $8.0(7.9-8.1)$ \\
\hline Length of mandibule & 15.5 & 15.0 & - & - & - & - & - \\
\hline Length of lower toothrow & 8.6 & 8.7 & $7.7(7.5-7.9)$ & 8.5 & 8.9 & - & - \\
\hline
\end{tabular}

locality; Shamel 1931), Piauí (Vizotto et al. 1980), Minas Gerais (Tavares et al. in press), São Paulo (Taddei \& Garutti 1981, Silva et al. 1996, Pedro et al. 2001), and Distrito Federal (Bredt 2003) (Figure 1). This is the first record for the State of Paraná and the southernmost record of N. aurispinosus for South America. The nearest localities where it has been reported are the Estação Ecológica de Caetetus (Pedro et al. 2001) and the city of São Paulo (Silva et al. 1996), which are $337 \mathrm{~km}$ north and $340 \mathrm{~km}$ northeast, respectively.

Some of these Brazilian records (e.g. Taddei \& Garutti 1981, Silva et al. 1996, Bredt 2003) are equally based on specimens captured in buildings and we recommend that bats sent to health centers for rabies test should also be forwarded to specialists for confirmation of identification. This procedure will certainly lead to an improvement of our knowledge on the diversity and distribution of rare and synanthropic species, particularly of molossid bats.

\section{Acknowledgements}

We are indebted to the Divisão de Vigilância em Zoonoses e Intoxicações (Secretaria de Estado da Saúde do Paraná), especially to Paulo de Araújo Guerra for their essential support, to Urubatan M. S. Suckow and Luiz Dino Vizotto for assistance with the data. We also thank two anonymous reviewers and Ariovaldo P. Cruz Neto, Sandra Bos Mikich, Fabiana Rocha-Mendes for editorial assistance and additional suggestions that improved the manuscrit, and Alexandre Lorenzetto and Carlos E. Conte for help in preparing the map.

\section{References}

ANDERSON, S. 1997. Mammals of Bolivia: taxonomy and distribution. Bull. Amer. Mus. Nat. Hist. 231:1-652.

BREDT, A. 2003. A experiência do Distrito Federal. In Manejo de quirópteros em áreas urbanas (I. Kotait et al., orgs.). Instituto Pasteur, Fundação Nacional de Saúde, Ministério da Saúde, São Paulo, p. 24-28. Manual Técnico do Instituto Pasteur, número 7/ Seminário Comemorativo dos 100 Anos do Instituto Pasteur.
CARTER, D.C. \& DAVIS, W.B. 1961. Tadarida aurispinosa (Peale) (Chiroptera: Molossidae) in North America. Proc. Biol. Soc. Wash. 74:161-165.

EGER, J.L. 2007. Family Molossidae. In Mammals of South America, Vol. 1: marsupials, xenarthrans, shrews, and bats (A.L. Gardner, ed). The University of Chicago Press, Chicago and London, p. 399-440.

FREEMAN, P.W. 1981. A multivariate study of the family Molossidae (Mammalia, Chiroptera): morphology, ecology, evolution. Fieldiana Zool. 7:1-173.

GARDNER, A.L. 2007. Mammals of South America, Vol. 1: marsupials, xenarthrans, shrews, and bats. The University of Chicago Press, Chicago and London.

GREGORIN, R. 2000. Filogenia de Molossidae Gervais, 1855 (Mammalia: Chiroptera). Tese de Doutorado, Universidade de São Paulo, São Paulo.

GREGORIN, R. \& TADDEI, V.A. 2002. Chave artificial para determinação de molossídeos brasileiros (Mammalia: Chiroptera). Mastozool. Neotrop. 9(1):13-32

IBÁÑEZ, C. \& OCHOA, G.J. 1989. New records of bats from Bolivia. J. Mammal. 70(1):216-219.

JONES Jr., J.K. \& ARROYO-CABRALES, J. 1990. Nyctinomops aurispinosus. Mammal. Spec. (350):1-3.

KOOPMAN, K.F. 1978. Zoogeography of Peruvian bats with special emphasis on the role of the Andes. Am. Mus. Novitates, (2651):1-33.

KOOPMAN, K.F. 1982. Biogeography of the bats of South America. In Mammalian Biology in South America (M.A. Mares \& H.H. Genoways, eds). University of Pittsburgh, Pittsburgh, p. 273-302.

LEGENDRE, S. 1984. Étude odontologique des représentants actuels fu groupe Tadarida (Chiroptera, Molossidae). Implications phylogétiques, systématiques et zoogeographiques. Rev. Suisse Zool. 91(2):399-442.

MILLER Jr., G.S. 1902. Twenty new American bats. Proc. Acad. Nat. Sci. Phila. 54(2):389-412.

OCHOA, G.J. 1984. Presencia de Nyctinomops aurispinosa en Venezuela (Chiroptera: Molossidae). Acta Cient. Venez. 35(2):147-150.

ORTIZ De La PUENTE, D.J. 1951. Estudio monografico de los quirópteros de Lima y alrededores. Publ. Mus. Hist. Nat. "Javier Prado", 7:1-48. 
PEDRO, W.A., PASSOS, F.C. \& LIM, B.K. 2001. Morcegos (Chiroptera; Mammalia) da Estação Ecológica dos Caetetus, estado de São Paulo. Chiropt. Neotrop. 7(1-2):136-140.

SANBORN, C.C. 1941. Descriptions and records of Neotropical bats. Field Mus. Nat. Hist. Zool. Ser. 27:371-387.

SANBORN, C.C. 1951. Mammals from Marcapata, southeastern Perú. Publ. Mus. Hist. Nat. "Javier Prado", 6:1-26.

SHAMEL, H.H. 1931. Notes on the American bats of the genus Tadarida. Proc. U.S. Natl. Mus. 78:1-27.

SILVA, M.M.S., HARMANI, N.M.S., GONÇALVES, E.F.B. \& UIEDA, W. 1996. Bats from the Metropolitan Region of São Paulo, Southeastern Brazil. Chiropt. Neotrop. 2(1):39-41.

SIMMONS, N.B. 2005. Order Chiroptera. In Mammal species of the world: a taxonomic and geographic reference. (D.E. Wilson \& D.M. Reeder, eds). Johns Hopkins University Press, Baltimore, p. 312-529.
TADDEI, V.A. \& GARUTTI, V. 1981. The southernmost record of the freetailed bat, Tadarida aurispinosa. J. Mammal. 62(4):851-852.

TAVARES, V.C., AGUIAR, L.M.S., PERINI, F.A., GREGORIN, R. \& FALCÃO, F. In press. Bat species (Chiroptera) recorded for the state of Minas Gerais, Southeastern Brazil. Biota Neotrop.

VIZOTTO, L.D., DUMBRA, A.J. \& RODRIGUES, V. 1980. Reencontro, no Brasil, de Tadarida aurispinosa (Peale, 1848) (Chiroptera-Molossidae). In Anais do VII Congresso Brasileiro de Zoologia. Escola Superior de Agricultura de Mossoró, Sociedade Brasileira de Zoologia, Fundação "Guimarães Duque", Mossoró, p. 100-102. Resumo dos trabalhos e conferências. Coleção Mossoroense, Volume CIX.

Received: $23 / 09 / 08$

Revised: $12 / 03 / 09$

Accepted: 20/05/09 